\title{
Estrogen Receptor Positive by Immunohistochemistry 81-90 Percent
}

National Cancer Institute

\section{Source}

National Cancer Institute. Estrogen Receptor Positive by Immunohistochemistry 81-90

Percent. NCl Thesaurus. Code C141475.

An immunohistochemical staining finding indicating that 81-90 percent of the cells in a

tissue sample are expressing estrogen receptor. 